\title{
Perceptions of Intern Nurses Regarding the Coronavirus (COVID-19) Pandemic: A Qualitative Study
}

\section{İntörn Hemşirelerin Koronovirüs (COVID-19) Salgınına İlişkin Algıları: Niteliksel Bir Çalışma}

\author{
DHava Gökdere Çinar¹, @Dilek Yılmaz', @Hülya Yılmaz² \\ 'Bursa Uludag University Faculty of Health Sciences, Department of Nursing, Bursa, Turkey \\ 2Bursa Uludag University Faculty of Medicine Department of General Surgery, Bursa, Turkey
}

\begin{abstract}
Aim: The Covid-19 pandemic has affected the individual and professional lives of all people, especially health professionals. For this reason, this study aimed to qualitatively determine the perceptions of intern nurses regarding the Covid-19 pandemic.

Material and Method: This phenomenological study was conducted with intern students receiving education at the final year of the nursing department of a state university in the Marmara Region of Turkey between November 1, 2020, and January 15, 2021. An in-depth face-to-face interview method was used in the study. In the interviews, four semi-structured interview questions developed by the researchers were directed to the participants, the answers were audiorecorded and the interviews were analyzed by content analysis by the researchers. The codes obtained as a result of the solution were collected under the main theme and sub-themes, which were created in a way that would provide meaning integrity.

Results: As a result of the data analysis, three main themes, seven sub-themes, and twenty-four codes were determined for the perceptions of the participants regarding the Coronavirus (Covid-19) pandemic. It was determined that many factors affected intern nurses' daily lives negatively and positively during the pandemic process and that participants resorted to some physical, psychological, and social methods to cope with the pandemic process. A group of intern nurses who performed clinical practice during the pandemic stated that this process had a positive effect on their individual development, their approach to patients, and their professional attitudes. Nevertheless, another group stated that their professional commitment decreased, that they felt worried and worthless, and that they avoided participating in the practices.

Conclusion: It was determined that intern nurses, the closest group to the nursing profession, were affected by the pandemic process in many positive and negative aspects, that their professional perceptions changed due to their concerns about the current situation and future, and that they used different techniques that supported and restrained their development in coping with the process. Educational institutions are recommended to provide motivation, counseling, and psychological support programs in order for student nurses to be able to manage their concerns, negative affections, and changing professional perceptions.
\end{abstract}

Keywords: Covid-19, intern nurse, nursing student, pandemic
Öz

Amaç: Covid-19 pandemisi tüm insanların olduğu gibi özellikle sağlık profesyonellerinin bireysel ve mesleki yaşamlarını etkilemiştir. Bu nedenle bu çalışma intörn hemşirelerin COVID-19 pandemisine ilişkin algılarının niteliksel olarak belirlenmesi amacıyla gerçekleştirilmiştir.

Gereç ve Yöntem: Fenomolojik (Olgu bilimi) bir çalışma olarak 1 Kasım 202015 Ocak 2021 tarihleri arasında Türkiye'nin Marmara Bölgesi'nde yer alan bir devlet üniversitesinin hemşirelik bölümü son sınıf intörn öğrencilerinin katılımı ile gerçekleştirilmiştir. Araştırmada yüz yüze derinlemesine görüşme yöntem kullanılmıştır. Görüşmelerde araştırmacılar tarafından geliştirilen dört adet yar yapılandırımış görüşme sorusu katılımcılara yöneltilmiş, yanıtlar ses kaydına alınmış ve görüşmeler araştırmacılarca içerik analizi yapılarak çözümlemeye gidilmiştir Yapılan çözümle sonucunda elde edilen kodlar anlam bütünlüğü sağlayacak şekilde oluşturulan ana tema ve alt temalar altında toplanmıştır.

Bulgular: Katılımcılardan toplanan verilerin analizi sonucunda koronovirüs (Covıd-19) pandemisine ilişkin algılarına yönelik üç ana tema, yedi alt tema ve yirm dört kod belirlenmiştir. Pandemi sürecinde intörn hemşirelerin günlük yaşamların olumsuz ve olumlu yönde etkileyen birçok unsur olduğu, pandemi süreciyle baş etmede fiziksel, psikolojik, sosyal bazı yöntemlere başvurdukları belirlenmiştir Pandemi süresince klinik uygulama yapan bir grup intörn hemşire bu sürecin bireyse gelişimlerini, hastaya yaklaşımlarını, profesyonel tutumlarını olumlu etkilediğin ifade ederken, diğer bir grup intörn hemşire ise mesleki bağlııklarının azaldığını, kendilerini kaygılı ve değersiz hissettiklerini ve mesleki uygulamalara katılmaktan kaçındıklarını belirtmişlerdir.

Sonuç: Hemşirelik mesleğini gerçekleştirmeye en yakın grup olan intörn hemşirelik öğrencilerinin pandemi sürecinden olumlu ve olumsuz birçok yönden etkilendiği, geleceğe ve anlık duruma ilişkin kaygıları nedeniyle mesleki algılarının değiştiği ve süreç ile baş etmede gelişimlerini destekleyen ve engelleyen farklı teknikler kullandıkları belirlenmiştir. Öğrenci hemşirelerin kaygılarını, olumsuz etkilenişlerin ve mesleğe ilişkin değişen algılarını yönetebilmeleri için eğitim kurumlarınca motivasyonu arttırıcı, danışmanlık ve psikolojik destek programlarını sağlamaları önerilmektedir.

Anahtar Kelimeler: Covid-19, intörn hemşire, öğrenci hemşire, pandemi. 


\section{INTRODUCTION}

The coronavirus (COVID-19) infection has affected the entire world and became a pandemic. The virus manifests itself as an acute respiratory syndrome in humans. ${ }^{[1]}$ COVID-19 emerged in late 2019 and spread to almost all over the world. According to the World Health Organization (WHO), it caused thousands of people to die. ${ }^{[2]}$

Home stays and decreased social relations for protection against the pandemic may cause psychological problems such as depression, fear, concerns of inadequate and inefficient healthcare services, sleep problems, and anxiety ${ }^{[3,4]}$ In a study conducted during the COVID-19 pandemic period, it was determined that $7 \%$ of individuals in the most affected regions of China developed post-traumatic stress symptoms one month after the onset of the pandemic. ${ }^{[5]}$ Furthermore, a study conducted with first-year nursing students reported that $85.9 \%$ of students experienced fear due to the COVID-19 pandemic. ${ }^{[6]}$

The COVID-19 pandemic has led to individual, national, and international intense effects. ${ }^{[7]}$ It has caused significant changes by affecting the economy, social life, and education, and especially the health system all over the world. ${ }^{[8]}$ Nurses fighting on the front line. The WHO declared 2020 as the "Year of the Nurse and Midwife". Due to the COVID-19 pandemic, the nursing profession has been on the world agenda, worthy as declared. Nurses have started to show that they are the "Nurses: A Voice to Lead in World Health" in 2020.9${ }^{11]}$ During the COVID-19 pandemic, the education process in all higher education institutions has been affected as well as health institutions. Countries have taken some measures in order to keep the spread of the virus under control and protect public health. Among these measures, education was temporarily suspended in many countries, including Turkey, and many educational institutions were temporarily closed. Many educational institutions have ensured the continuity of education with distance education. ${ }^{[10]}$ In this process, the Council of Higher Education (CoHE) declared that the spring semester of the 2019-2020 academic year would be given by distance education in universities ${ }^{[8,12]}$ Although distance learning had not been frequently used before the COVID-19 pandemic, it has been used as an alternative learning method due to the inability to provide face-to-face education during the pandemic period. ${ }^{[8]}$

Some nursing students, the health professionals of the future, had their practical courses in health institutions during the onset of the COVID-19 pandemic period. This may have caused fear and anxiety. As a matter of fact, according to the relevant studies, nursing students experience stress, fear, and anxiety during the pandemic process. ${ }^{[6,13-16]}$

While the COVID-19 pandemic was continuing, clinical practice courses were continued with the distance education method for lower grades in the fall semester of 2020 whereas final-year intern nursing students received their clinical practice courses in the hospital. Therefore, this may have led intern students to concerns, changed professional attitudes, and some mood changes. In this sense, it is necessary to determine the perceptions of intern nursing students regarding the COVID-19 pandemic. According to the literature, qualitative research approaches provide the opportunity to obtain detailed information about the attitudes, beliefs, motivations, and behaviors of society members. ${ }^{[17,18]}$ Based on this idea, this study aimed to qualitatively determine the perceptions of intern nurses, who are the prospective health professionals of the future, regarding the COVID-19 pandemic. It is thought that the findings of this study will contribute to the literature, determine the factors affecting the perceptions of intern nurses and how they are affected, and provide the opportunity to make developmental interventions when necessary.

\section{MATERIALS AND METHOD}

In order to conduct the research, necessary legal permissions were received from the Scientific Research Commission of the Ministry of Health, General Directorate of Health Services (Permission number: 2020-05-02T04-41-52) and the ethics committee of the university where the study was conducted (Dated: 1 June 2020, Decision number: 2020-05). All procedures were carried out in accordance with the ethical rules and the principles of the Declaration of Helsinki.

\section{Research Type and Time}

This research was planned as a qualitative phenomenological study. Phenomenology is not only a philosophical approach but also a research method in which certain methods are used in order to understand the perceptions, interests, and experiences of an individual. ${ }^{[19]}$ The research was carried out with final-year intern students at the nursing department of a state university in the Marmara Region of Turkey between November 1, 2020, and January 15, 2021.

\section{Research Population and Sample}

The population of the research consisted of students receiving education in the final year of the nursing department (arastirmanin evreni?). The sample consisted of 21 intern nurses who voluntarily agreed to participate in the study.

\section{Data Collection}

Students who agreed to participate in the study were informed about the study and their consent was taken. The students were told that all data would be used for scientific research. In addition, the researchers explained that the answers of the students will not affect the course grades in any way. In the study, a semi-structured interview form developed by the researchers was used as a data collection tool. In order to reveal the perceptions of the students regarding the COVID-19 pandemic, an in-depth interview method was used and 4 open-ended questions were asked in the interview. The clarity of the interview form and the suitability of the questions were rearranged after receiving the opinion of five faculty members who are specialists in their fields. Accordingly, the following questions were asked to the students. 
- How has the COVID-19 pandemic effected your daily life?

- What methods have you used to cope with the COVID-19 pandemic?

- How do you think performing your clinical practice in a pandemic hospital during the COVID-19 pandemic affects your practices?

- If you give care to an individual diagnosed with COVID-19 when you start working after graduation, what feelings do you think you would experience?

On the basis of confidentiality, the opinions of the participants were coded without using their names. Each student was given a code name (S1, S2, S3 ....... S21). In the interviews, questions were asked to the students using the face-to-face interview technique and verbal communication and listening skills. The interviews were audio-recorded with a voice recorder and notes were taken by the researcher at the same time. All interviews with the students were held in the same environment (teaching staff's office). Interviews lasted an average of 10-12 minutes for each student. The students were informed about the audio recordings; their written consent was taken and the interviews were recorded on a voice recorder.

\section{Data Analysis}

After the completion of the interviews, the audio recordings and the notes were transcribed and manual content analysis was performed by the researchers. The outputs generated after the analysis were read many times and a code list was created. During coding, the researchers reached a consensus on thematic explanations describing the findings. Subthemes and main themes were determined by classifying the generated codes according to their content integrity.

\section{RESULTS}

As a result of the content analysis, three main themes, seven sub-themes, and twenty-four codes were determined for the perceptions of intern nurses regarding the coronavirus (COVID-19) pandemic (Table 1).

\section{Theme 1. Effects of the Pandemic Process on Daily Life}

Expressions of intern students regarding the effects of the pandemic process on their daily lives were discussed in two sub-themes: "Positive Effects" and "Negative Effects".

\section{Sub-Theme 1. Positive Effects}

Intern students mentioned the positive effects on their daily lives during the pandemic and emphasized the codes of "development of planned work habits", "strengthening of family ties", "finding opportunities for personal development", "reduction in noise pollution". Below are examples of interviews statements about the codes that positively affected their daily lives.

“...I started doing everything... in a planned way." (S1)

"...noise pollution is less since there are fewer people outside..." (S10)

“...our family ties have become stronger. You know, we spend more time together because of the fear that something would happen to one of us." (S13)

"...I learned to value ... the time I spent at home. I learned to spend time at home instead of going out. I read a book, take time for myself. I dedicate myself to personal development and I am happy at the same time..." (S16)

Table 1. Main Themes, Sub-Themes, and Codes for the Perceptions of Intern Nurses Regarding the Coronavirus (COVID-19) Pandemic.

\begin{tabular}{|c|c|c|}
\hline MAIN THEMES & SUB-THEMES & CODES \\
\hline \multirow{2}{*}{$\begin{array}{l}\text { 1- Effects of the pandemic process on } \\
\text { daily life }\end{array}$} & 1-Positive effects & $\begin{array}{l}\text { Development of planned working habits } \\
\text { Strengthening of family ties } \\
\text { Finding opportunities for personal development } \\
\text { Reduction in noise pollution }\end{array}$ \\
\hline & 2-Negative effects & $\begin{array}{l}\text { Psychological problems } \\
\text { Physical problems } \\
\text { Social problems } \\
\text { Family problems } \\
\text { Problems related to the education process }\end{array}$ \\
\hline \multirow{3}{*}{$\begin{array}{l}\text { 2- Methods used to cope with the } \\
\text { pandemic process }\end{array}$} & 1-Physical methods & $\begin{array}{l}\text { Using protective materials } \\
\text { Using antiseptics and disinfectants } \\
\text { Enhancing immunity }\end{array}$ \\
\hline & 2-Psychological methods & $\begin{array}{l}\text { Avoidance of information } \\
\text { Keeping up with up-to-date information } \\
\text { Developing repetitive behaviors }\end{array}$ \\
\hline & 3-Social methods & $\begin{array}{l}\text { Social distance } \\
\text { Social isolation }\end{array}$ \\
\hline \multirow{2}{*}{$\begin{array}{l}\text { 3- Effects of professional clinical } \\
\text { practices during the pandemic process }\end{array}$} & 1-Positive effects & $\begin{array}{l}\text { Increased awareness } \\
\text { Ability to empathize with patients } \\
\text { Improvement in professional behavior skills }\end{array}$ \\
\hline & 2-Negative effects & $\begin{array}{l}\text { Decreased commitment to the profession } \\
\text { Feeling worthless } \\
\text { Increased anxiety } \\
\text { Avoidance of participating in practices }\end{array}$ \\
\hline
\end{tabular}




\section{Sub-Theme 2. Negative Effects}

Intern students mentioned the negative effects on their daily lives during the pandemic and emphasized the codes of "psychological problems", "physical problems", "social problems", "family problems", "problems related to the education process". Below are examples of interviews statements about the codes that negatively affected their daily lives.

"...In my family, my mother and sister work. We, three people, live at home. For example, I cannot hug them. We have always started to keep a distance, even in family relations, due to the fear of getting infected at any moment..." (S1)

"...I was going out to cafes, spending time with my friends. If I didn't do any of them, I would come to school. In other words, there was an environment where I could meet with my friends. They all stopped at once and we stayed at home." (S3) "...I can say it changed a routine. It changed my school schedule, my living conditions. I stayed away from education. We would have a five-month internship; I would be able to improve myself even more. Right now, I'm trying to do what I can in a two-week period." (S4)

"..I am very worried. Because my anxiety is high in general. I used to have panic attacks sometimes, ...It affects me. However, I can adapt after a while. Of course, I will do everything I can. Because I will be a health professional. I will try to do my job even if I am anxious." (S6)

"...I used to wear a single mask, now I started wearing two masks. I normally wash my hands a lot and I started to wash them even more. I even had dermatitis on my hands." (S8)

\section{Theme 2. Methods Used to Cope with the Pandemic Process}

The methods that intern students used to cope with the pandemic process were addressed in three sub-themes: "Physical Methods", "Psychological Methods", and "Social Methods".

\section{Sub-Theme 1. Physical Methods}

Intern students mentioned the physical methods they used to cope with the pandemic process and emphasized the codes of "using protective materials", "using antiseptics and disinfectants", and "enhancing immunity". Below are examples of interviews statements about the codes regarding the physical methods they used to cope with the pandemic.

"...I wear a mask; I wash my hands more, and so on. I try to stay away from people, but I know that it will infect everyone... Most importantly, I try to keep my immune system strong. I pay attention to my diet." (S4)

"...not going out without a cologne, having spare masks, having gloves... not accepting guests, not entering public areas, not going to places such as cafes unless necessary. We only use public transportation only when necessary..." (S5)

"...I had a blood test to know if there is anything wrong. I take supplementary vitamins so that my body resistance does not decrease... My vitamin D level was low. I also take 2000 or 4000 units of Magnesium a day. Apart from that, I pay attention to what I eat; I also try to exercise." (S10)

\section{Sub-Theme 2. Psychological Methods}

Intern students mentioned the psychological methods they used to cope with the pandemic process and emphasized the codes of "avoidance of information", "keeping up with upto-date information", and "developing repetitive behaviors". Below are examples of interviews statements about the codes regarding the psychological methods they used to cope with the pandemic.

"... for example, when I come home, I wash my hands for at least one or two minutes, even I am at home. For example, I go out on the balcony at home; I get fresh air; I use cologne or something when I go back to the room... As soon as I feel that I am in contact with the outside, I wash my hands for at least one or two minutes." (S6)

"...we do research, of course. We do research online. We look at the news to learn. This is how we try to adapt." (S11)

"... at first I was avoiding learning about COVID-19. As if there was no such thing. In my normal routine, I had been reading books or watching movies or TV shows. And then, after getting into life so much, I started researching COVID-19; I started learning." (S16)

\section{Sub-Theme 3. Social Methods}

Intern students mentioned the social methods they used to cope with the pandemic process and emphasized the codes of "social distance" and "social isolation" codes. Below are examples of interviews statements about the codes regarding the social methods they used to cope with the pandemic.

"We had to impose restrictions on our daily lives. We started to do less of the things we normally do routinely. We started to pay more attention, not to go out unless necessary, and to reduce social activities." (S5)

"...for example, I go out, but I go to the seaside; I sit alone; I do not get involved with anyone." (S2)

"Now I had to limit my social activities. ...I try to use public transportation very little; if the distance is short so that I can walk, I try to walk or try to use a taxi. I used to go to cafes a lot; I used to go to astro pitch football games; now I try to reduce them. I don't go to cafes. I don't go to crowded restaurants." (S7)

"...I always pay attention to social distance. I like to follow the rules. You know, when I walk on the road, I always keep my distance with people." (S8)

\section{Theme 3. Effects of Professional Clinical Practices During the Pandemic Process}

Expressions of intern students regarding how they were affected by clinical practices during the pandemic process were discussed in two sub-themes: "Positive Effects" and "Negative Effects". 


\section{Sub-Theme 1. Positive Effects}

The positive effects of clinical practice that intern students had during the pandemic were discussed under three codes: "increased awareness", "ability to empathize with patients", and "improvement in professional behavior skills". Below are examples of student interview statements regarding the relevant codes.

"...in fact, how careless we were about hygiene in our previous lives. For example, when I left a patient room, I had not washed my hands. Right now, I immediately say 'No! We are in the pandemic process...' Then I said that this is what should have happened" (S16)

"...we are nurses, so everyone employed in the health sector must have taken all kinds of things into consideration when choosing this profession. Anything can happen. It is a pandemic today; it could end; it could start again, or it could be something else." (S2)

"...we empathize...I think of my family. It could have been my mother in this place; it could have been my father. Everyone deserves good health care, a good care." (S17)

"... Of course, but I provide care professionally." (S9)

"...after I started working in the field, I wanted to start by learning something better. ... not just because of the pandemic, there are many diseases that are contagious, that can be transmitted through droplets. It seems like we will be more prepared; If I had started working right now without experiencing this internship, maybe I would have been more afraid. Now I have both got used to it and better learned and understood the measures. I can put it into practice in a better way." (S12)

\section{Sub-Theme 2. Negative Effects}

The negative effects of clinical practice that intern students had during the pandemic were discussed under four codes: "decreased commitment to the profession", "feeling worthless", "increased anxiety", "avoidance of participating in practices". Below are examples of student interview statements regarding the relevant codes.

"...I will be assigned next year and I don't even think about assignment. Because if I get sick in the future..." (S1)

"...I have fear, anxiety. It is for my family more than myself because I still live with my family. I mean, I'm afraid for them more than myself. Frankly, I don't want to infect them, even if I get infected... I try to avoid contact as much as possible, but I still have to provide care..." (S3)

"...I wouldn't want to do the clinical practice. Why should I risk myself? You also have the potential to harm your loved ones; that's why I wouldn't want to work." (S4)

"...I feel worthless. Because ... doctors try not to contact as much as possible. I always have to, others can avoid, but everyone knows that I will have to contact... because you act as a bridge. In other words, the value given to patients is not given materially, spiritually, or in terms of position..., in no way." (S18)

\section{DISCUSSION}

The COVID-19 pandemic, which started in Wuhan, China at the end of 2019, disturbed both the personal and professional lives of people all around the world. ${ }^{[20,21]}$ Nursing students were among the most affected groups due to the changing experiences, organizational differences, uncertainties about their competencies, uncertainties about the education process. ${ }^{[22]}$ For this reason, the study was carried out to examine the perceptions of intern nursing students who went into clinical practice during the pandemic process regarding the COVID-19 pandemic. In line with the results obtained, it was determined that the students were affected by the pandemic process both positively and negatively. It was seen that social solidarity was at a high level in our country especially during the pandemic and that our solidarity ties were tested due to the pandemic. ${ }^{[23]}$ The students who participated in the study stated that the ties within the family, the smallest building block of society, got stronger and that they spent more time together. Likewise, Felaza et al. (2020) stated in their study that medical students strengthened their family ties during the pandemic process. ${ }^{[24]}$ On the other hand, since carbon emissions in various parts of the world decreased, the atmosphere was cleaned, nature began to recover, and the pollution of the seas stopped. The deteriorated environmental balance has begun to be reestablished. ${ }^{[23]}$ Participants in the study similarly mentioned a reduction in noise pollution. Students, who could evaluate the COVID-19 pandemic positively despite its negative effect on life, stated that this traumatic process offered opportunities to study in a planned way, read books, and spend time for personal development. Similarly, Asıcı and Günlü (2020) obtained positive findings in their study that the pandemic process increased personal development and awareness among students. ${ }^{[25]}$ Thus, the COVID-19 pandemic may have positively contributed to the growth, development, and empowerment of some young individuals, the improvement of family ties, and the compensation for the damage humanity has done to the world.

The pandemic process has negatively affected health professionals in physical, psychological, and social aspects. ${ }^{[26]}$ The students who participated in the research also mentioned many negative physical, psychological, social, familial, and educational effects on their daily lives during the pandemic process. In the interviews, the students stated that they decreased their contact even in the family due to the fear of infection, stayed away from the environments such as schools and cafes where they got social, stayed away from the education system they were accustomed to, had less clinical practice in the professional field, had psychological problems such as panic attacks and repetitive behaviors, and developed dermatitis due to the increase in washing frequency. According to the literature, nursing students are afraid of the COVID-19 pandemic and have psychological problems. ${ }^{[26,27]}$ It is obvious that social relations will not be the same as before after the COVID-19 pandemic, at least for a certain period of time. This can increase social alienation since people 
can see each other as potential virus carriers. ${ }^{[23]}$ Furthermore, there are shortcomings in the practice training of final-year students who will provide one-to-one nursing care in health institutions, creating pressure on students. The social distance rule that requires being away from friends and home stays are difficult for young people to tolerate; therefore, it can be suggested that nursing students are under intense stress in terms of academic, familial, health, and social relations during the pandemic process.

Coping with anxiety and stress during outbreaks is very important in order to improve the effects of anxiety and stress on health. ${ }^{[28]}$ Strategies for coping with this process are multidimensional and include many different ways such as problem solving, information seeking, avoidance, support seeking, social isolation. ${ }^{[28,29]}$ When the literature was examined, it was seen that the viral COVID-19 infection affects people with low immunity more easily. ${ }^{[30]}$ The guidelines of the WHO and the Turkish? Ministry of Health have recommended paying attention to adequate and balanced nutrition, preferring healthy foods, regular exercise, adequate sleep, and meditation in order to reduce susceptibility and longterm complications caused by the coronavirus. ${ }^{[31]}$ Moreover, social isolation, which is one of the most effective weapons in coping with this process, includes individuals staying away from crowded environments and paying attention to the physical distance between people. ${ }^{[32]}$ In the study, intern students mentioned hygiene practices (handwashing, use of masks, gloves, disinfectants), immune-supportive activities (proper nutrition, physical activity, vitamin supplement, health examinations), social distance, and social isolation (staying away from the crowded, not leaving the house, not accepting guests, moving by opening the distance between people) as the methods they used to cope with the pandemic process. In addition, some participants stated that they suppressed their anxiety by avoiding getting information about the disease in coping with this process whereas other participants stated that they could continue the process by keeping up with up-to-date information and tried to adapt. It was thought that this negative process, which has caused mandatory life changes such as quarantine, might be an opportunity to gain habits such as proper nutrition, exercising, hygiene habits, compliance with the rules, and obtaining information from the right sources.

Nurses as a health professionals fighting COVID-19 on the frontline and will be key players in ending the pandemic with appropriate support. ${ }^{[9]}$ For this reason, it is desired result to continue to train nurses in higher education institutions in order to solve the global nurse demand in case of increasing crisis. $^{[33]}$ Clinical practice is a critical yet complex and challenging component of the professional development of nursing students. ${ }^{[34]}$ Therefore, distance education and mixed methods have created opportunities to complete this challenging education process component in the COVID-19 pandemic. ${ }^{[35]}$ In other words, in order to overcome this crisis period with the least damage, nursing students received their practical courses in the hospital environment and their theoretical lessons with distance education during the COVID-19 pandemic. ${ }^{[9]}$ This process had both positive and negative effects on students. The participants stated that they were able to better implement many protective measures that they had not paid attention to before, that this process increased their awareness, that they could now better empathize with patients, and that they felt prepared for negative health conditions that may occur in the future. In a qualitative study conducted by Swift et al. (2020) ${ }^{[36]}$ with undergraduate nursing students, students stated that they could be useful during the pandemic process and that the society's positive response to their effort would also positively affect their career preferences. However, the literature also includes negative feedback from students in clinical

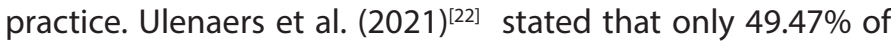
students could establish a balance between clinical practice and private life. Yılmaz and Büyüköztürk (2021) determined that nursing students had concerns about getting infected by COVID-19 ${ }^{[37]}$, being in contact, and infecting their family members, patients, or health professionals, being a carrier, and about an interruption of their education. Slettmyr et al. (2019) $^{[38]}$ and Sampaio et al. (2021) ${ }^{[39]}$ also determined in their studies that students experienced noncompliance between self-protection or protecting their loved ones and the urge to "do their part". Studies also mentioned that the anxiety levels of students who live with their families and who have chronic diseases increase. ${ }^{[40-42]}$ Çalışkan et al. (2020) ${ }^{[43]}$ also showed in their study that the fear of COVID-19 negatively affects the level of attitude towards the nursing profession. In the study conducted by Kızıltepe and Yılmaz (2021), students stated that nurses had fear/anxiety of being sick, that they did not want to enter the patient's room, that communication with patients was limited due to the necessity of working with protective equipment, that they spent less time with patients, that they paid less attention to contact with patients, that the care provided to patients was severely interrupted, and that the quality of care decreased. ${ }^{[41]}$ Likewise, intern students participating in our study stated that their professional commitment decreased due to being involved in clinical practice during the pandemic, that they were hesitant about working after graduation, that they were worried about their and their families' health, that being on the front line made them feel worthless, that they felt uncomfortable about not having the right to withdraw from care while everyone had it, and that they were not supported financially and morally. Although the research findings are consistent with the literature, it makes us question how the motivation resources will support students' commitment to the profession during the education process.

\section{CONCLUSION}

This study aimed to examine the perceptions of intern nursing students who have been in clinical practice during the pandemic process, regarding the COVID-19 pandemic. 
In line with the results obtained, it was determined that the students were able to find opportunities to support their personal development during the pandemic process, but they also had negative psychological, physical, social, familial, and educational experiences. Although some students developed healthy lifestyle behaviors in coping with the process, it was observed that they encountered psychological problems due to the anxiety they experienced. During the pandemic, intern nursing students who went to clinical practices were affected both positively and negatively in professional, emotional, and familial aspects. However, at the end of the research process, it was thought that students need more motivation support in an ominous process such as a pandemic and that the current support mechanisms should be reconsidered by educational institutions. Educational institutions are recommended to increase professional ties with improved counseling services regarding the pandemic process and all future extraordinary situations. A psychological support program to be provided along with the distance education process is thought to help students in this regard.

\section{ETHICAL DECLARATIONS}

Ethics Committee Approval: In order to conduct the research, necessary legal permissions were received from the Scientific Research Commission of the Ministry of Health, General Directorate of Health Services (Permission number: 202005-02T04-41-52) and the ethics committee of the university where the study was conducted (Dated: 1 June 2020, Decision number: 2020-05).

Informed Consent: All patients signed the free and informed consent form.

Referee Evaluation Process: Externally peer-reviewed. Conflict of Interest Statement: The authors have no conflicts of interest to declare.

Financial Disclosure: The authors declared that this study has received no financial support.

Author Contributions: All of the authors declare that they have all participated in the design, execution, and analysis of the paper, and that they have approved the final version.

\section{REFERENCES}

1. Zhou $P$, Yang $X L$, Wang $X G$, et al. A pneumonia outbreak associated with a new coronavirus of probable bat origin. Nature 2020;579(7798):270-3.

2. World Health Organisation [WHO] 2015. Global strategy on human resources for health:Workforce 2030, Retrieved from http://www.who.int/ hrh/resources/globstrathrh-2030/en/ Date of access:16.04.2020

3. Okuyan CB, Karasu F, Polat F. Hemşirelik öğrencilerinin Covid-19'a maruz kalma korkularının sağlık kaygısı düzeyleri üzerine etkisi:bir üniversite örneği. Van Sağlık Bilimleri Derg 2013;20 (Covıd-19 Özel Sayı):45-52.

4. Torales J, O'Higgins M, Castaldelli-Maia JM, Ventriglio A. The outbreak of COVID-19 coronavirus and its impact on global mental health. Int J Soc Psychiatry 2020;66(4):317-20.

5. Liu N, Zhang F, Wei C, et al. Prevalence and predictors of PTSS during covid-19 outbreak in China hardest-hit areas:Gender differences matter. Psychiatry Research 2020;287:112921.
6. Yılmaz D, Yılmaz DU. An Examination of the relationship between fear of coronavirus (Covid-19) in first year nursing students and their attitudes to the profession. Curr Health Sci J 2021;47(3):331-7.

7. Pakpour AH, Griffiths MD. The fear of covid-19 and its role in preventive behaviors. J Concurr Dis 2020;2(1):58-63.

8. Kızıltepe SK, Kurtgöz A. Hemşirelik öğrencilerinin covid-19 pandemisi sürecinde aldıkları uzaktan eğitime yönelik tutum ve görüşlerinin belirlenmesi. J Int Soc Res 2020;13(74);558-66.

9. Çevirme A, Kurt A. Covıd-19 pandemisi ve hemşirelik mesleğine yansımaları. Avrasya Sosyal ve Ekonomi Araştırmaları Derg 2020;7(5):46-52.

10. Can E. Coronavirüs (Covid-19) pandemisi ve pedagojik yansımaları: Türkiye'de açık ve uzaktan eğitim uygulamaları. Açıköğretim Uygulamaları ve Araştırmaları Derg 2020;6 (2):11-53.

11. International Council of Nurses (ICN) Nursing the World to Health - ICN announces theme for International Nurses Day 2020. Date of access:16.04.2020 https://www.icn.ch/news/nursing-world-health-icnannounces-theme-international-nurses-day-2020

12. YÖK. (2020b). https://yokdersleri.yok.gov.tr/ (Date Of Access:10.10.2020).

13. Aslan H, Pekince $H$. Nursing students' views on the covid-19 pandemic and their percieved stress levels. Perspectives in psychiatric care 2021;57(2):695-701.

14. Savitsky B, Findling Y, Ereli A, Hendel, T. Anxiety and coping strategies among nursing students during the covid-19 pandemic. Nurse Educ Pract 2020;46:102809.

15. Turan GB, Özer Z, Çiftçi B. Analysis of anxiety levels and attitudes of nursing students toward the nursing profession during the Covid-19 pandemic. Perspect Psychiatr Care 2021; 57(4):1628-36.

16. Yanık D, Yeşilçınar İ. Covıd-19 pandemi sürecinde yaşanan sosyal izolasyonun hemşirelik öğrencileri üzerindeki etkileri:Niteliksel araştırma. Sağlık Akademisyenleri Derg 2021; 8(2):103-12.

17. Brookes D. Understanding the value of qualitative research in nursing. Nursing times 2007;103(8):32-3.

18. Çopur EÖ, Can Z, Çam H, Karasu F. Hemşirelik araştırmalarında nitel çalışmaların önemi. Gümüşhane Üniversitesi Sağlık Bilimleri Derg 2020;9(4):396-401.

19. Hesse-Biber S, Leavy P. (). The practice of qualitative research. California: Sage Publications 2006. p. 3-33.

20. Findyartini A, Anggraeni D, Husin JM, Greviana N. Exploring medical students' professional identity formation through written reflections during the Covid-19 pandemic. J Public Health Res 2020;9(s1):1918.

21. Bal IA, Arslan O, Budhrani K, Mao Z, Novak K, Muljana PS. The balance of roles: Graduate student persectives. Tech Trends 2020;64(6):796-8.

22. Ulenaers D, Grosemans J, Schrooten W, Bergs J. Clinical placement experience of nursing students during the covid-19 pandemic:a crosssectional study. Nurse Educ Today 2021;99:104746.

23. Afacan E, Avcı N. Korona virüs (Covid-19) örneği üzerinden salgın hastalıklara sosyolojik bir bakış. Avrasya Sosyal ve Ekonomi Araştırmaları Derg 2020;7(5):1-14.

24. Felaza E, Findyartini A, Setyorini D, Mustika R. How motivation correlates with academic burnout:study conducted in undergraduate medical students. Educ Med J 2020;(12):43-52.

25. Asıcı E, Günlü A. Üniversite öğrencilerinin gözünden covıd-19 salgını:Nitel bir araştırma. Gençlik Araştırmaları Derg 2021;(9.Özel Sayı):1-25.

26. Al-Rabiaah A, Temsah MH, Eyadhy A, et al. Middle East Respiratory Syndrome-Corona Virus (MERS-CoV) associated stress among medical students at a university teaching hospital in Saudi Arabia. Journal of infection and public health. J Infect Public Health 2020;13(5):687-91.

27. Lovrić R, Farčić N, Mikšić Š, Včev A. Studying during the covıd-19 pandemic: A qualitative inductive content analysis of nursing students' perceptions and experiences. Educ Sci 2020;10(7):188.

28. Son C, Hegde S, B Eng, Smith A, Wang X, Sasangohar F. Effects of COVID-19 on College Students' Mental Health in the United States:Interview Survey Study. J Med Internet Res 2020;22(9):1-14.

29. Demaray MK, Ogg JA, Malecki CK, Styck KM. Covıd-19 stress and coping and associations with internalizing problems in $4^{\text {th }}$ through $12^{\text {th }}$ grade students. School Psychol Rev 2021;1-20. 
30. Aman F, Masood S. How Nutrition can help to fight against covid-19 pandemic. Pakistan J Med Sci 2020;(36):121-3.

31. Butler MJ, Barrientos RM. Brain, behavior, and ımmunity the impact of nutrition on covid-19 susceptibility and long-term consequences. Brain Behav Immun 2020;(87):53-54.

32. Perlman D, Patterson C, Moxham L, et al. Understanding the influence of resilience for people with a lived experience of mental illness:A selfdetermination theory perspective. J Comm Psychol 2017;45(8):1026-32.

33. World Health Organizations (WHO) announces COVID-19 outbreak a pandemic. Accessed from http://www.euro.who.int/en/health-topics/ health-emergencies/coronavirus-covid-19/news/news/2020/3/whoannounces-covid-19-outbreak-a-pandemic, on April 2020.

34. Spence D, Zambas S, Mannix J, Jackson D, Neville S. Challenges to the provision of clinical education in nursing. Contemp. Nurse 2019;(55):45867.

35. Prokes C, Housel J. Community college student perceptions of remote learning shifts due to covid-19. TechTrends 2021;(65): 576-88

36. Swift A, Banks L, Baleswaran A, et al. Covid-19 and student nurses:A view from England. J. Clin. Nurs 2020;29(17-18):3111-4.

37. Yılmaz Ş, Büyüköztürk $M$. Anxiety encountered by nursing students in clinical practices during coronavirus outbreak. BSJ Health Sci 2021;4(3):257-63.

38. Slettmyr A, Schandl A. Arman M. Hemşirelikte fedakarlı̆̆ın belirsizliği:Nitel bir çalışma. Hemşirelik Etiği 2019;26(2):368-77.

39. Sampaio F, Sequeira C, Teixeira L. Impact of covid-19 outbreak on nurses' mental health: A prospective cohort study. Environ Res 2021;(194):110620.

40. Sandalcı B, Uyaroğlu OA, Güven GS. Covıd-19'da Kronik Hastalıkların Rolü, Önemi ve Öneriler. Flora 2020;25(5):1-7.

41. Kızıltepe SK, Yılmaz Ş. Hemşirelik öğrencilerinin koronavirüs korkusu ile bakım davranışları arasındaki ilişkinin incelenmesi:tanımlayıcı bir araştırma. Turkiye Klinikleri J Nurs Sci 2021. DOI:10.5336/ nurses.2021-84438

42. Sundarasen S, Chinna K, Kamaludin K, et al. Psychological Impact of covid-19 and Lockdown among University Students in Malaysia:Implications and Policy Recommendations. Int J Environ Res Public Health 2020;17(17):6206.

43. Çalışkan $E$, Kargın $M$, Ersöğütçü $F$. Hemşirelik öğrencilerinde covid-19 korkusu ile hemşirelik mesleğine yönelik tutum arasındaki ilişki. J Cont Med Educ 2021; 30 (3):170-180. 